\title{
Nuevos datos sobre el teatro en la ciudad de Guatemala (1789-1820)
}

\section{INTRODUCCION}

$\mathbf{L}^{\wedge}$ A serie de documentos inéditos que aquí saco a luz se halla actualmente en el Archivo General del gobierno, en la ciudad de Guatemala. ${ }^{1}$ La ortografía se conserva fielmente, alterándose sólo la puntuación para mayor claridad. Los datos se refieren en su mayor parte a los teatros provisionales, patios usados asimismo para otras diversiones. En 1803 había, al parecer, tres: el patio de las casas de Cabildo y de la Hermandad de San Juan de Dios; el de gallos; y el del cuartel de la plaza de Santa Rosa. En 1818 habia disponibles cuatro provisionales, inclusive el patio de gallos. El único teatro regular, edificado hacia fines del siglo xvin, quedó destruido antes del año 1818. El Cabildo -después del 11 de diciembre de 1812 le tocaba el derecho exclusivo de atender a los problemas relativos al teatro- nombraba comisionados, los cuales exigían, en el caso de celebrar fiestas especiales, que se stministrase información relativa a la iluminación y decoración del teatro, el vestuario, las comedias, los sainetes, etc. Un alcalde ordinario, encargado de mantener el buen orden, estaba presente durante cada función, que principiaba a las siete de la noche los días de fiesta. Compañías de volatines contaban entre sus habilidades entremeses, pantomimas y comedias. Representaciones de titeres, basadas sobre las tramas de varias comedias, divertían al público en 1818. Unos actores mexicanos iban a Guatemala a actuar. ${ }^{2}$ Desgraciadamente se citaron pocos títulos de comedias, pero las obras del siglo de oro del teatro español, i. e. comedias de Moreto y Calderón, todaría gozaban de bastante populari- 
dad. Se descubre muy poco en los documentos acerca de los costos de las representaciones, pero en 1789 un empresario estuvo dispuesto a poner en escena tres piezas por la suma de dos mil quinientos pesos. Los días de representación daba el empresario cierta suma, como limosna, al Hospital de San Juan de Dios. El motivo de las representaciones especiales fué el celebrar la coronación de un rey, la llegadia de un nuevo presidente, o las fiestas de ciertos santos. Para las más solemnes fiestas religiosas se acostumbraba a tener sermones, procesiones, música, bailes de moros, etc., acompañados a veces por sucesos escandalosos. ${ }^{\mathbf{3}}$

E1 1ํ de agosto de 1789 Lorenzo María Porras, vecino de la nueva ciudad de Guatemala, of reció representar, por la suma de dos mil quinientos pesos, tres comedias para las fiestas que se preparaban con pretexto de la exaltación al trono del rey Carlos IV. ${ }^{4}$ Dejaría la elección a los señores del Cabildo, Justicia y Regimiento de la ciudad, con tal de que se escogiesen las obras cuya representación no fuese ni demasiado costosa ni impracticable. Afianzó su postura con la hipoteca de una casa. La ciudad prometería entregarle quinientos pesos en el día que se extendiese la escritura, mil pesos el 1 de octubre y los mil restantes después de haber cumplido con sus obligaciones. Antes de considerar la oferta los dos comisionados propusieron que Porras suministrase información respecto al plano, alzado, iluminación, decoración, máquinas, etc. del teatro, mostrase algunos de los trajes de los actores e indicase el número de sainetes que se habían de entreverar. Porras, aún no recibida una respuesta ocho días después de hacer su propuesta, se querelló manteniendo que el asunto no permitía dilación por lo corto del tiempo. También volvió a tratar de las hipotecas de su casa, procurando demostrar que la ciudad no incurría en ningún peligro financiero. Concluyó por decir que, en caso de no determinar el asunto dentro de tres días, abandonaría el proyecto. Los dos señores regidores comisionados se quedaron firmes en los puntos, ya señalados en su anterior informe, respecto al teatro, sugiriendo que Porras pudiese tomar por ejemplares para manifestar sus ideas estas tres comedias: El mayor monstruo los celos, de Calderón de la Barca; Antíoco y Seleuco, probablemente la de este título que escribió Moreto; y La confusión de un jardín, de Moreto. El síndico procurador general era de la opinión de los comisionados, pero con la condición de que la suma que se 
pagase a Porras no excediese de dos mil pesos. Si el postor no se conformase con esta reducción, propuso el síndico que los comisionados trataran de dirigir por sí la fiesta y preparar la zarzttela. Enterado Porras de la determinación el 20 de agosto, respondió que ya apremiaba tanto el tiempo que sólo podría llevar a cabo sus planes por tres mil pesos y dejando la elección de las piezas teatrales a su arbitrio. Por eso, pidió que el Ayuntamiento le devolviese "las diligencias originales y plano presentado." $\mathrm{Y}$ asi se hizo. En su segundo informe, de fecha 18 de agosto, Porras, irritado por la expresión de desconfianza relativa a sus intenciones para poner en escena las comedias, había elaborado mucho su descripción del teatro. Este se cubriría con una gran vela movible, con pinturas de las musas y Apolo. Habría quince bastidores para las dos mutaciones en cada comedia. Para asegurar la iluminación adecuada, tendría tres arañas y muchos candiles, setenta colocados en la orilla del tablado y otros entre bastidores. Se representarían sainetes nuevos. E1 vestuario sería apropiado para los papeles de reyes, príncipes, galanes y damas. En tres carteles se pondrían unas octavas que servirían para denotar el título de la comedia. Por fin, mostró Porras que la representación de El mayor monstruo los celos no of receria ninguna dificultad de construcción. Si Porras hubiese podido poner en escena las comedias, los comisionados, para asegurarse que todo correspondía al plan presentado, hubieran hecho una visita de inspección al teatro, un mes antes de la ejecución de las comedias, para ver un ensayo.

Más tarde en el mismo año, el 4 de diciembre de 1789, José Guillermo Segura, con el fin de colaborar en celebrar la entrada del nuevo señor presidente, ofreció proporcionar, de acuerdo con el agrado del Ayuntamiento, una o tres comedias de los siguientes títulos, todas de Moreto: El desdén con el desdén, Primero es la honra, e Industrias contra finezas. La representación no ocasionaría a la ciudad más gastos de los que resultaran de la postura del teatro, la música y los refrescos, con la condición de que se le concediese después licencia para representar en casas particulares, pudiendo así "sacar los costos que impendiere en pagar cómicos, vestuarios y músicos." E1 síndico procurador general replicó que la primera parte de la propuesta no era admisible porque "estos gastos los soportan los caudales de los particulares que sirven los oficios consejiles de este Cabildo y su lasto no se eroga de el fondo y caxa 
de este Noble Ayuntamiento." No dijo nada el documento -al parecer ya no era necesario- respecto a la petición del suplicante de representar en casas particulares.

Juan José Núñez, de parte de una compañía de volatines que trabajaba "en todo género de habilidades, como son en maroma, saltos nunca vistos, alambre floxo, bayles, cuerda floxa, sombras chinescas, entremeses, sombras inpalpables, pantominas (sic) y comedias", se hallaba sin lugar para sus representaciones, puesto que el Ayuntamiento no le había concedido ni el patio de las casas de Cabildo y de la Hermandad de San Juan de Dios ni el de gallos. Desesperado por estas circunstancias, Núñez suplicó que se le franquease el patio del cuartel de la plaza de Santa Rosa. El 2 de abril de 1803 se le otorgó el permiso solicitado, a condición de que cada día de representación entregase seis pesos, como limosna para los pobres del Hospital de San Juan de Dios. Conforme a las providencias de costumbre, se estipuló asimismo que uno de los alcaldes ordinarios asistiese a cada función para mantener el buen orden. Algunos días después, el 16 de abril, dos señores como diputados por la Hermandad de Caridad del Real Hospital de San Juan de Dios, divulgaron que habían convenido en alquilar el patio de gallos a una compañía de volatines, cuya cabeza era Vicente Sánchez (con toda probabilidad se trata de la misma compañia). Se prometió poner en la cabecera del patio un tablado, como de seis varas en cuadro. La compañía asumiría todos los gastos precisos para las representaciones y cobraria un real de entrada. Se cobraría para el hospital cuanto "Su Señoría señale por rasón de asciento, según las clases de los que la misma Hermandad proporcionará al público". Se convino en que las funciones de la compañía no se diesen en los días de gallos y que se excluyesen, por falta de espacio suficiente en el lugar, las diversiones de maroma, columpio y saltos, las cuales se reservarían para las tardes en otro patio. Se darían representaciones todas las noches de fiesta y las demás noches que permitiera el Superior Gobierno.

Pío Castro, vecino de la capital y actor de la compañía de don Miguel el mexicano, rogó permiso, siempre que ese empresario se fuese, para continuar la representación de comedias en las noches de fiesta. Cobraría un real a los adultos y medio a los niños. Su solicitud fué negada el 12 de enero de 1813 . 
En 1818 Mariano Arriaga, natural mexicano que se avecindaba en la Antigua Guatemala desde hacía seis años, pidió licencia para dar en la capital unas representaciones de títeres. En su repertorio se incluían comedias, sainetes, cantos, etc.; la mayor parte la daba al estilo mexicano:

El enemigo de las mujeres; El Marquez de Volipón y tonto Tirulito; la petrimeta ( $\mathrm{sic}$ ) corregida o ser̃orita embustera; La fingida comedia y perdón de la enferma; Un loco hace ciento; El celoso Carranza; El minero y barras de plata; El muerto celoso; El chasco de los colegiales y el Crispin zapatero; El narido burlado; La hipocresía remedada y el sordo Tapia, con otras muchas piezas curiosas, sus sainetes y cantos anegsos ( $\mathrm{sic}$ ), todo remedado en su treato ( $\mathrm{sic}$ ) pintoresco con un juego de estatuas de edad de siete años fingiendo las voses correspondientes, sin que intervengan mugeres en ello, ni contenga cosa alguna contra nuestra santa fe católica; guíenos contra lo político, antes bien moral instructivo, que inspira horror a los vicios; la mayor parte de lo representado es al estilo de México.

Estaba dispuesto a dar sus representaciones en las tres noches de la próxima Pascua, cobrando medio real por la entrada. Esperaba tener las funciones "en la casa misma en donde es el juego real del asiento de gallos." Como el señor síndico no encontró nada censurable en las piezas que se le pasaron, se le concedió la licencia a Mariano Arriaga para los tres días de Pascuas. Cumplido el convenio y, deseoso de seguir con sus representaciones. Arriaga volvió a pedir permiso, esta vez para una larga temporada, o sea "hasta para el tiempo de Carnestolendas del año próximo entrante." Asimismo, impetró se le dejase proporcionar en el Real Palacio la diversión para la noche del cumpleaños de su Excelencia, o para otra en que quisiese dar entretenimiento a los niños. En respuesta a dicha solicitud, el síndico se declaró en oposición, porque acababa de recibir otros dos pedimentos de igual naturaleza y se molestarían, si todos trabajasen al mismo tiempo. Dió su preferencia a José María Alanís porque éste podría aportar diversiones más variadas $y$, siendo maestro dedicado a ese oficio, era de suponer, más dignas de presentación. Se hallaron lógicas las razones del síndico y fueron declarados sin lugar los pedimentos de Arriaga y Francisco Martínez, el tercero de los solicitantes. 
Otros documentos del mismo año (1818) revelan que el mencionado Francisco Martínez era el dueño del patio de gallos, cuyo producto hasta aquel entonces no le había indemnizado su inversión. Tomado en cuenta el mal estado de los teatros en la capital y las incomodidades de sus sitios y convencido de la inclinación del pueblo a esa clase de diversiones - a pesar de la irregularidad de las funciones en el pasado, de la incapacidad de los actores y de la mala dirección de los asentistas - se decidió a rogar licencia para convertir su fábrica en teatro provisional, esperando en consecuencia sacar mayores ganancias. Quería que se la concediesen para iniciar las representaciones el $1^{\circ}$ de noviembre, comenzando los programas a las siete de la noche de los días de fiesta. Por la concesión daría cien pesos a la real hacienda. E1 síndico avisó que José Oñate ya había entablado una petición semejante con el fin de construir un coliseo que sería de uso permanente. El edificio de Martínez, en cambio, serviría sólo para una corta temporada. También propuso el síndico que se nombrase una comisión para averiguar si el patio de gallos tenía capacidad, firmeza y otras comodidades necesarias para un teatro. Conforme a esta sugestión, se designaron para el reconocimiento del patio de gallos cuatro oficiales, inclusive el arquitecto Santiago Marqui, quien en su informe afirmó: que el techo estribaba sobre débiles pilares de madera, sin la consistencia requerida para sostener tanto peso en caso que hubiese temblores; que las puertas eran demasialo pequeñas y angostas. Martínez contestó a estos puntos con la aserción que Marqui en el expediente contradijo lo que había repetido verbalmente ante los otros comisionados y que aquel señor hasta había aceptado el cargo de dirigir la obra de construcción. Continuó, asegurando que la solidez de la fábrica de gallos ya estaba probada, habiendo sido reconocida, después de terminada en 1815, por el coronel de ingenieros Juan Bautista Jáuregui y habiendo resistido sin lesión alguna un sinnúmero de fuertes terremotos. En su referencia desdeñosa a otros coliseos de la ciudad - los calificó de sombras o esqueletos de coliseos- descubrió "que se destruyó el único formal que se plantó ha más de veinte años" 5 y que se habían dado representaciones teatrales en el antiguo patio de gallos provisional y en el del sitio frente al patio actual. Amargamente agregó que en su opinión el voto de Marqui había sido parcial, puesto que éste favorecía a José Oñate, ${ }^{6}$ quien quería construir 
un edificio permanente, $y$ sin duda creía que la concesión a Martínez estorbaría los planes del otro suplicante. Concluyó la solicitud rogando se nombrase al coronel Jáuregui para que realizase un nuevo reconocimiento de la fábrica de gallos. El citado coronel, terminado su trabajo, dió la razón a Martínez en todo. No encontró nada que le hiciese desconfiar de la seguridad del edificio. Aunque delgados, los pilares eran de una excelente calidad de roble y bastante fuertes para aguantar mucho peso. También pensaba Martínez aumentar el número de éstos, poniendo otro pilar en medio de cada vano de los que sostenían el piso superior. La puerta, admitido que fuese pequeña, la proponía ensanchar Martínez hasta dos varas. El coronel también notó que las dos escaleras eran angostas, pero no se corría peligro de atropellamiento, visto que cabía poca gente en el piso de arriba. Al parecer, el dueño del patio de gallos tenía la intención de poner otra escalera en uno de los costados y cumplir obras proyectadas para el tablado y los palcos. Con dichos mejoramientos el coliseo quedaria seguro y mucho más cómodo que cuantos provisionales, generalmente sin techo, había tenido la ciudad en el pasado.

El síndico, después de analizar los contradictorios informes proporcionados por los dos ingenieros, halló insuperable un obstáculo, la estrechura de las escaleras y puertas, de modo que no podian pasar las personas excepto de una en una. No faltarian por aquel tiempo corridas de toros, que estaba tratando de proporcionar la Hermandad de Caridad, y las pantomimas y representaciones dramáticas de José María Alanís, dándose éstas, sin correr peligro el público, en una casa cómoda. Además, era de la opinión que la ciudad no podía soportar tantas diversiones a la vez y por eso se debiera negar el permiso a Martínez. Este, de carácter testarudo y enterado del favorable informe del ingeniero Juan Bautista Jáuregui, dió expresión a la esperanza de que ya no habría dificultad en conseguir la licencia solicitada. Pero, en caso de surgir aún algún obstáculo, propuso otros sitios para el teatro-provisional: el que se hallaba frente al actual patio de gallos y otro de dos allí inmediatos. Era verdad que a todos éstos les faltaban las ventajas del patio de gallos, que estaba cubierto y equipado con asientos firmes. Confiado en las palabras de los comisionados que cumplieron el primer reconocimiento de su patio, Martínez no había creído que hubiese dificultades y en consecuencia ensayó algunas comedias, pagó los actores, e 
incurrió en otros gastos. Así fué que en caso de no poder representar las obras, le resultaría un grave quebranto. Volvió a referirse a las pérdidas que sufría en el remate de gallos. El Ayuntamiento todavía se oponía, por las razones anteriormente entmeradas por su síndico, a otorgar la licencia pedida. Asimismo era de la opinión que en aquella temporada ya gozaba el público de suficientes diversiones sin agregar otras.

En 1820 el señor Cayetano Bedoya se dirigió a su Excelencia solicitando permiso para abrir un coliseo provisional en la ciudad de Guatemala. Los síndicos, fundadas sus opiniones en el decreto del 11 de diciembre de 1812, le avisaron "ser exclusivo de los Ayuntamientos todo lo relativo a diversiones públicas y arreglo de teatro". Las prevenciones del citado decreto autorizaron al Ayuntamiento para que hiciese los convenios con los empresarios; requiriese la entrega al jefe político de una lista de piezas en el repertorio de las comparías, de esa manera pudiendo excluir las que fuesen censurables; cuidase de la policía de los teatros; interviniese en la administración de las compañías solamente en caso de no cumplirse "las cargas que puedan imponerse, con arreglo al ajuste, sobre el producto de los teatros para objetos de beneficio común"; tratase de terminar gubernativamente las desavenencias que se originasen entre los empresarios y los cómicos.

\section{NOTAS A LA_INTRODUCCION}

1 Aprovecho aquí la ocasión de expresar mi agradeciniento al señor profesor Philip W. Powell, estimado amigo y colega, quien con suma bondad puso a mi disposición sus fotografías de los documentos reproducidos en este estudio.

2 Las memorias de fray Antonio de Molina, escritas en los años 16771678, contienen algunas de las primeras noticias sobre el teatro de Guatemala y aluden a dos comediantas de México que fueron allá : "Este año de '40 [1640] salió por alcalde ordinario de Guatemala don Ignacio de Guzmán, a quien mataron una noche alevosamente a 13 de febrero. No duró más que dos días porque murió miércoles 15 del dicho mes. Quiero contar esta muerte con alguna extensión porque lo pide el caso. Vinieron a esta ciudad de Guatemala dos comediantas llamadas la una Catalina y la otra Teresa. Era la Catalina (a quien llamaban la Cata, y por este nombre era más conocida) muy hermosa. 
Con ésta se amistó el don Ignacio de Guzmán. Estanclo en estat amistad, vinieron de México dos hombres en busca de estas mujeres porque antes habían tenido mala amistad con ellos; llanábase el uno Sebastián Pérez y el otro Diego Ximenes, platero. Sabiendo que ya la Cata estaba amistada con don Ignacio, sintiólo mucho y quiso tomar venganza mas no de suerte que matase al caballero. Quiso darle de cintarazos no más, y una noche que fué la del día 13 de febrero salieron estos dos a hacer el hecho que tenían pensado. $Y$ yendo a mula con la comedianta a las ancas, en la puerta de la cárcel de Corte le dieron una puñalada en las verijas que lo dexaron por muerto porque caió de la mula pidiendo confesión. Huyeron estos dos y el Ximenes, pareciéndole que no había hecho más que darle de cintarazos, iba refiriendo el caso a su compañero, el cual dicen que le dixo que él no había dado cintarazos sino estocada. A todo esto el don Ignacio no sabía quién le había herido, y llevándole a su casa el beático, los dos fueron y vieron al enfermo, ya de muerte por la herida que le habían dado. $\mathrm{Y}$ viendo el riesgo que corrían se retraxeron en San Francisco con todo recato y silencio. Duró poco al saberse donde estaban porque el Marqués hizo tales diligencias que se hubo de descubrir donde cstaban. Cercaron el convento y los entraton a buscar y los hallaron ya rapados y como frailes para disimularse y huirse. Lleváronlos presos a la cárcel de Corte... Lo que quiero contar para que se asombren los que esto leyeren, y sepan qué cosa son mujeres mundanas, es que a la Cata la llevaron a la cárcel, y al tiempo de ajusticiar a estos dos hombres, ella salió a una ventana pequefia que cae a la plaza, tan sin dársele nada, que estaba leyendo in libro de comedias, y al tiempo de arrojar al uno de la escalera, lo que hizo fué volver la cara para verlo no más, y luego volvió a leer en su libro, y habiendo ahorcado al segundo, volvió no más de a mirarlo y continuó después su lección de su comedia; que éstas fueron las oraciones que rezó por dos hombres a quienes ella había puesto en la horca. Salió después ella de la cárcel, porque como era tan hermosa, hubo muchos que le tuvieron lástima. Contentáronse con desterrarla, y a poços días se volvió a Guatemala a representar de inevo, como yo lo vide; y el año de 1658 que estuve en México, conocí al gracioso - bufón de las comedias que ellas representaban aquí en Guatemala, haciendo el mismo oficio. Llamábase N. Navarro." Véase Autonio de Molina, Antiguta Guatenala, Guatemala, 1943, pp. 28-30.

3 Véase mi estudio "Edición de La historia de la comberción de San Pablo, drama guatemalteco", que espero publicar dentro de poco.

4 Veintinueve años habían transcurrido sin que los colonos tuvicsen ocasión de festejar el advenimiento de un nuevo soberano y esta circunstancia motivó que la coronación de Carlos IV fuese celebrada entusiastamente con representaciones teatrales en todos los dominios españoles de Anérica: Catamarca, Buenos Aires, Islas Malvinas, Salta, Montevideo, Santiago de Clile, Guanajuato (México), Pátzcuaro, Papantla, Tabasco, Celaya, Arcquipa, Lima, Araure (Venezuela), Bogotá, etc. Véanse Ricardo Rojas, Historia de la literatura argentina, Buenos Aires, 1918, II, 439; J. Luis Trenti Rocamora, El teatro en la América colonial, Buenos Aires, 1947, pp. 31, 216, 229, 273, 394- 
396; Guillermo Furlong, Músicos argentinos durante la dominación hispánica, Buenos Aires, 1944, p. 153; Armando de Maria y Campos, Andanzas y picardías de Eusebio Vela, México, 1944, pp. 197-198; Guillermo Lohmann Villena, El arte dramático en Lima durante el virreinato, Madrid, 1945, pp. 503-504; José Juan Arrom, Documentos relativos al teatro colonial de Venezuela, publicación separada de la Universidad de La Habana, 1946, p. 16; Ignacio Gutiérrez Ponce, Crónicas de mi hogar en la época colonial (1536 a 1818), London y Tonbridge, 1926, pp. 579-582.

5 Las cantidades gastadas en el año de 1793 en la construcción del coliseo, a que se hace referencia aquí, llegaron a la suma de 8.080 pesos 2 reales. "Había entonces las siguientes localidades: mosquete o platea, gradas, lunetas, aposentos o palcos y cazuela... Llamóse a este teatro 'de Camato', por el nombre del empresario..." Véase Ramón A. Salazar, Historia del desenvolvimiento intelectual de Guatemala: La colonia, Guatemala, 1897, r, 248-251.

6 Oñate fundó en 1819 un teatro al que dió su nombre. Ibid., p. 251. 
Propuesta de Don Lorenzo [María] Porras de tres comedias para las fiestas reales de $\mathrm{S} u$ Majestad Carlos Quarto

Informe del escribano de hypotecas sobre las que tenga la casa que se propone:

Don Lorenzo María Porras de este vecindario, como más haya lugar ante Vuestra Señoría, parezco y digo: que, a consecuencia del oficio passado por los dos señores, diputados por Vuestra Señoría al Coronel Don Fernando Porras, mi hermano, en razón de la propuesta que hizo sobre poder disponer tres comedias para las fiestas que se preparan con el plausible objeto de la coronación de Nuestro Católico Monarca Señor Don Carlos Quarto, he sido llamado para formalizarla, respecto a que la referida propuesta la hizo por mí el mensionado (sic), mi hermano, y, en esta inteligencia desde luego me obligo a disponer las referidas tres comedias y desempeñar estas funciones por el precio de los dos mil y quinientos pessos propuestos, con calidad de que hayan de ser las que Vuestra Señoria elija con consideración si a las circunstancias (sic) del país, angustia del tiempo y precio de ellas, pues tal vez podría elejirse alguna que no pudiera costearse sola con los dos mil y quinientos pessos o fuera aquí adsolutamente (sic) inpracticable, ya y / para tomar las medidas que sean oportunas, se servirá Vuestra Señoria mandar que, sin ninguna dilación, se me haga saver quáles devan ser; en cuyos términos, desde luego, afianzo esta postura con la ipoteca (sic) de una cassa que tengo por mía, puesta en esta capital, abaluada según resulta del justo y precio que presento en quatro mil ciento setenta $\mathrm{y}$ tres pessos tres reales y que el escribano de ipotecas certifique si está inscripta la espresada cassa en el catastro principal, vien entendido que en casso de acertarse mi propuesta en la conformidad insinuada, deverán entregárseme en el día que se estienda la escritura quinientos pessos, mil pessos el día primero de octubre inmediato y los mil restantes, después de evaquadas las operaciones. Sobre que Vuestra Señoría resol- 
berá lo que estime combeniente. Nueva Guatemala y agosto 1 de 89. Lorenzo María Porras.

El decreto de este acto lo proveyeron y rubricaron los. señores del Cabildo, Justicia y Regimiento de esta ciudad. En Nueva Guatemala / y agosto tres de mil setecientos ochenta y nuebe años. Joseph Manuel de Laparte.

\section{Muy Ylustre Señor}

La casa, de que se trata, está especialmente hypotecada por Don Lorenso María de Porras, según escriptura que paçó (sic) ante Don Josef Díaz Gonzales, en 24 de diziembre del año de 786, al seguro de doscientos pesos que debe entregar cada año de los cinco en que se le remató el assiento de la aguardiente, en los valles de Sanzaria y Tocoy, ${ }^{1}$ cuya obligación está también asegurada con fianza in solidum de Don Miguel de Asmitia, como más por menor consta del libro de mi cargo, donde se sientan (sic) esta taxa de gravámenes.

$Y$ cállase también con otro esta misma cassa y es el de la especial hypoteca, con que se asegu- / ró a favor de Don Vicente Garzía de Salas, por el mismo Porras, la cantidad de nobecientos nobenta y dos pesos dos y medio reales, importe de una memoria de géneros de Castilla que le tomó al fiado, ofreciéndoselos pagar en el mes de marzo del año de ochenta y ocho, conforme al instrumento otorgado por el susodicho escribano, en fecha de 29 de diziembre del de 785 , como resulta del mismo libro, a que me remito. $Y$ tanto esta razón, como la antecedente no tienen la de estar canceladas estas obligaciones. Nueva Guatemala y agosto 5 de 1789. Joseph Manuel de Laparte.

Con lo que informen los señones comissionados passe al señor syndico.

El decreto lo / proveyeron y rubricaron los señores del Cabildo, Justicia y Regimiento de esta ciudad. Nueva Guatemala y agosto seis de ochenta y nuebe. Joseph Manuel de Laparte.

\section{Muy Ylustre Señor}

Para poder calificar esta postura, es necesario que se presente un prospecto o diseño del teatro en que se hallan (sic) de representar las comedias, tanto de su plano quanto de su alzado, iluminación y decoración, espesificándose las mutaciones y cortinón que se piensen poner y máquinas para su pronto movimiento. Asimismo se deverán manifestar los trajes con 
que hayan de pareser los interlocutores, según las diverzas clazes y tiempos de las comedias, exemplarizando tanto los vestidos quanto las mutaciones con una o dos de distinto / carácter y expresándoze el número de saynetes que se hallan de entreverar. De este modo, no más, se podrá formar concepto de la representación que se propone y si será correspondiente a la sublimidad de la fiesta y al lustre de Vuestra Señoria y entonzes podrán los comisionados informar a Vuestra Señoria lo que estimen conveniente. Nueva Guathemala, agosto 7 de 1789. Pedro de Ayzinena y Larrayn. Martín de Valdés.

\section{Muy Ylustre. Señor}

El síndico procurador general reproduce por su oficio lo que los señores regidores commisionados informan en su antecedente. Nueva Guatemala y agosto 12 de 1789. Mariano Náxera.

Passen a los señores comissionados y syndico en el / día y agréguese el escrito presentado en esta fecha.

Lo qual proveyeron y rubricaron los señores del Cabildo, Justicia y Regimiento de esta ciudad. Nueva Guatemala y agosto catorce de mil setecientos ochenta y nuebe. Joseph Manuel de Laparte. /

Señor Don Josef Laparte. Muy señor mío: Enviaré a vuestra merced, que en virtud de lo mandado por el Nobilisimo Alluntamiento (sic) se sirva entregar a Don Josef Belasco los papeles míos, y tenía presentado con el plano. Dios Nuestro Señor guarde a viestra merced muchos años. Desta la casa, y agosto 26 de 1789 . Besa las manos de uestra merced. Su seguro servidor. Lorenzo Maria Porras. /

Los papeles irán ya a poder del señor Joseph Velasco, anticipando tres pesos, que con otro tanto más importan mis derechos. / En 14 de agosto.

\section{Muy Ylustre Señor}

Don Lorenzo María de Porras, como más lugar aya ante Vuestra Señoria, parezco y digo: que, aviendo tenido noticia de que con el plausible motivo de la coronación de Nuestro Católico Monarca, deseava Vuestra Señoria que se hiziessen algunas comedias, por lo que me presenté, diciendo que por dos mil y quinientos pessos que se me diessen me obligava a 
hazer tres, las que fuessen del agrado de Vuestra Señoria, y aunque haze más de ocho días que hize esta propuesta, hasta ahora no se a resuelto en razón de su admisión o repulsa. Con este motivo, teniendo mis interesses abandonados, de que se me sigue grave perjuicio, y mucho más, que el tiempo que / resta para disponer las referidas tres comedias es ya muy angustiado y assí este asunto no admite ninguna dilación. El reparo único que pudiera ponerse es el de las ipotecas que tiene mi cassa a favor de las rentas de aguardientes y Don Bizente García. Lo de la renta eran mil pessos por cinco años, pero, aviendo corrido y pagado dos de éstos, sólo se restan seiscientos pessos que están asegurados con fiadores; $y$, por lo respetivo a Don Vicente García, desde luego sede éste el derecho de prelación que pudiera tener en la cassa por razón de su ypoteca a favor de esta ciudad, como lo acredita el documento que devidamente presento; con lo que pareze no queda reparo en la admisión de la ypoteca y, más, cuando con ella lo que se intenta assegurar no son más que un mil y quinientos pessos, pues los mil restantes, conforme a mi propuesta, no se me deven entregar hasta después de echar las comedias. No tengo empero en que se admita o no la propuesta, pero sí en que se determine luego su admisión o repulsa / para tomar las medidas que en uno $u$ otro ebento me conbenga $y$, por tanto, a Vuestra Señoría suplico se sirva determinar con la brevedad que essixe (sic) este. asunto, si se admite o no, en inteligencia de que en casso de no poderse resolber dentro de terzero día, desde luego me aparto de la propuesta que tengo hecha por las razones insignuadas, que es justicia que pido. $\mathrm{Va}$ entre renglones $=10 \mathrm{q} u \mathrm{e}=$ vale. Lorenzo María Porras.

\section{Muy Ylustre Señor}

En atención a que no puede calificarse postura alguna sin saverse sus calidades y a que la de hacer representar tres comedias, también se cumplirá con una comedia bien representada en treato ( $\mathrm{sic}$ ), correspondiente como con una malamente hecha $y$ en un tablado de cortinas, no pueden los comisionados absolutamente deliberar y así reproducen a Vuestra Señoria su anterior / informe, poniendo por exemplares para que el postor manifieste su idea: la del Mayor monstruo de los celos, Anteoco y Seleuco y La Confución (sic) de un jardín. ${ }^{2}$ Nueva Guatemala, agosto 14 de 1789. Pedro de Ayzinena y Larrayn. Martín de Valdés. 


\section{Muy Ylustre Señor}

El síndico procurador general, con vista de lo nuebamente espuesto por lo señores rexidores comicionados, repruduse (sic) lo dicho para, con vista de lo que el postor manifieste, hazer el pedimento correspondiente. Nueva Guathemala $y$ agosto catorse (sic) de mil setecientos ochenta y nuebe. Mariano Náxera.

Corra traslado a Don Lorenzo Porras de lo expuesto por los señores comisionados y síndico, agregando los antecedentes.

Lo qual / proveyeron y rubricaron los señores del $\mathrm{Ca}$ bildo, Justicia y Regimiento. Nueva Guatemala y agosto treze de mil setecientos ochenta y nuebe. Joseph Manuel de Laparte.

\section{Muy Ylustre Señor}

El síndico procurador general de Vuestra Señoria dice: que adhiere al dictamen de los señores comicionados, pero con calidad de que no exeda de dos mil pesos lo que se dé al postor quien, si se acomodare a este precio, podrá prosederse a la extención de la escritura con todas las firmezas nezesarias, y precediendo el que Don Vicente García reconosca judicialmente el documento suyo, que se ha precentado. Pero si no se aviniere, podrá Vuestra Señoría, siendo muy servido, mandar que los señores / comicionados traten desde luego de dirigir por sí esta clase de fiestas, valiéndose de personas inteligentes o preparar la sarsuela acordada. Y sobre todo Vuestra Señoría determinará lo que estime más combeniente. Nueva Guathemala y agosto dies y nuebe de mil setecientos ochenta y nuebe. Mariano Náxera.

Vistos: Como dice el señor syndico y hágasele saber al postor. Pavón. Gốmara. Obregón. Romá. Manrique. Gil. Oyarzával. Ayzinena.

Lo qual proveyeron y firmaron los señores del Cabildo, Justicia y Regimiento de esta ciudad. Nueva / Guatemala y agosto diez y nuebe de mil setecientos ochenta y nuebe años. Joseph Manuel de Laparte.

En veinte de agosto de mil setecientos ochenta y nuebe hize saber el auto antecedente a Don Lorenzo Porras, quien, inteligenciado de su tenor, dixo: que, respecto a que no se le ha admitido la propuesta que hizo y que en el día es ya muy estrecho el tiempo, desde luego se desiste y aparta de ella; pues, en las circunstancias presentes, ni por tres mil pesos se resolvería hacerse cargo de la representación, porque, siendo 
ya abanzada la coronación sería menester gastar más dinero para habilitarlas que el que habría gastado si se le huviesse admitido oportunamente, y sólo había seguido en la propues15 ta, por cumplir con la palabra dada, pues, según lo pro- / metido, considera infaliblemente quedarse sin casa y expuesto a pedir limosna; por lo que sólo podría seguir en la postura si se le diessen los tres mil pesos y a su arbitrio las comedias y sin las circunstancias que piden los señores comissionados; que esta inteligencia suplica al Nobilísimo Ayuntamiento que se le devuelvan en el día las diligencias originales y plano presentado. Esto respondió y firmó por ante mí. Doy fe. Lorenzo Maria Porras. Joseph Manuel de Laparte. /

Don Lorenzo María Porras de este vezindario, como más lugar haia (sic) ante Vuestra Señoría, paresco y digo: que de orden de Vuestra Señoria se me ha corrido traslado del pedimento de los dos señores rejidores diputados para el assumpto de comedias que se intentan hazer, y del señor síndico procurador general, al que contexto, diciendo que lo que of resí en mi primer escrito fué desempeñar este asumto (sic) y de ninguna manera quedaría si mi intención ubiera sido el poner cuatro cortinas y una mal representada comedia. Por lo que en deuida forma presento a Vuestra Señoría el diseño o teatro con todas las dimenciones correspondientes, $y$, porque en tan corto espacio no se podían figurar todos los requisitos correspondientes, hago sauer a Vuestra Señoria: Lo primero: que este teatro se cubrirá con un belón en el qual hirán (sic) pintadas las nueve musas con sus resprectibos nombres que se explicarán por medio de unas redondillas, presidiendo a éstas Apolo en lo alto.de un monte en donde hirán repartidas; este belón subirá para arriba con velocidad por medio de ocho garruchas y seis hombres que lo mueban, y para su dessenso lo hará el peso correspondiente. Lo segundo: que las mutaciones, que se le han de poner por medio de quince bastidores que ban figurados, serán dos en cada comedia, agregándose a éstas las

17 que forsozamente tubieren / aquellas que Vuestra Señoría elija. El pronto mobimiento de estos bastidores se hará, illendo (sic) estos embutidos en sus canales y los que con belocidad nesessitasen de mutación entre la jornada se moberán por medio de sigüeñas, y quando no, como quiera que el cortinón no sube para otra cosa que para ocultar la mutación siguiente se hará ésta con facilidad en tanto se resita o canta el sainete fuera del dicho cortinón en el espacio de dos varas que que- 
dan hasta la orilla del teatro, como se verá en la figura número 3. Lo tercero: que la iluminación de este teatro se hará por medio de tres arañas, que hirán pendientes en la cornisa de afuera, setenta candiles que se pondrán en la orilla, a más de esto entre uno y otro bastidor hirán unas arandelas en donde se pondrán luzes y candiles, dándoles sus reflejos para que iluminando lo de fuera queden ocultos a la vista. Lo quarto: que en cada comedia habrá al fin de la jornada un sainete nuebo. Lo quinto: que los vestidos de los ynterlocutores que ofresco son aquellos muy desentes que halla para reyes, príncipes, galanes y acompañanta para las damas vestirlas con aquellos trajes y painados (sic) correspondientes según sus papeles. Pues, de ninguna manera correspondería al lustre de Vuestra Señoría, ni al punto mío que se presentasen con vestidos ridículos. En la fachada del plan se representan tres carteles, en donde se colocarán unas octabas que denote cada una el título de la comedia y por remate a los lados de las armas reales se descubren dos banderas, en donde se piensan colocar las armas de Vuestra Señoría, y las del gobierno, expresando Vuestra Señoria la preferencia de unas y otras en caso de ser de su agrado. Otros requisitos y menudencias excuso significar por no molestar la atención de Vuestra Señoría, que siendo mui serbido se serbirá permitirme licencia para entrar y verbalmente hazerlo y contextar (sic) a algunas objeciones que se me pueden poner.

Asimismo se me manda que exemplarise sobre tres / títulos que se me dan de comedias, lo que hago diciendo: que en la de El mayor monstruo, los celos, en la primer jornada se arroja por el tetrarca, un puñal al mar. Este se puede formar por medio de unos bastidores de bambalinas, que es bastantemente fácil su construcción. En la segunda jornada no aparese más que figurar una puerta y dos soldados, uno sobre otro, que, teniendo el teatro seis varas de claro, no parese aí dificultad alguna. En la tercera no se encuentra otra que obscureser el tablado, lo que se practica con brebedad, apagando las luzes interiores. $Y$, por fin, presentado como lo hago un plan general, no parese habrá dificultad para variar qualquiera mutación quando ésta se puede verificar por medio de agregar - quitar un bastidor.

Por tanto, a Vuestra Señoria suplico nuevamente se sirva determinar en el mismo día, pues de estas demoras se me originan maiores gastos, pérdida en mis intereses; y caso de verificarse el que se hagan las referidas comedias, la estrechés del tiempo que es lla (sic) tan corto que parese aun imposible practicar lo propuesto, no llebando otro interés más que el desempeñar a Vuestra Señoria y cumplir la palabra que se 
dió, pues la alta consideración de Vuestra Señoría no dejará de premeditar así lo dicho, como el que según las ideas formadas, no se podrán costear con lo pedido. Es Justicia \&.

Otrosí digo: que, en qualquier ebento de haserse o no las referidas comedias, se me debuelba asi el plan como las demás diligencias originales, $\mathrm{q} u$ e es justicia que pido $v t$ supra. Lorenzo María Porras.

19 Vuelva a los señores comissionados y fecho al señor / syndico en el día por la brevedad de que necesita.

Lo qual proveyeron y robricaron (sic) los señores del Cabildo, Justicia y Regimiento de esta ciudad. Nueva Guatemala y agosto diez y ocho de mil setecientos ochenta y nuebe. Joseph Manuel de Laparte.

\section{Muy Ylustre Señor}

Está a satisfacción de los comisionados el prospecto $y$ plan, que se presenta del teatro / en que hayan de celebrarse las tres comedias; y si la execución corresponde a la ydea se logrará una función brillante. Pero si les parese exesiva la cantidad de 2.500 pesos, cuio concepto han formado mediante cálculos formados por personas inteligentes, por lo que si el postor haze alguna baja podrá Vuestra Señoria admitirle la postura con la presisa condición de que el teatro corresponda en un todo al plan presentado, que un mes antes de la execución se haya de manifestar en ensayo a los comicionados, para que puedan enmendarse sus faltas, si acaso tubiere alguna, $y$ que del mismo modo se hallan de mostrar con anticipación los trages y vestiduras para ver si corresponden a la época $y$ nación de la comedias. Vajo cuios presupuestos no encuentran / los comicionados embarazo en que, otorgando antes la correspondiente escritura, se le entregue el dinero que pide adelantado. Nueva Guathemala y agosto dies y nueve de mil setesientos ochenta y nueve. Pedro de Ayzinena y Larrayn. Martín de Valdés.

Esta representación es de colocarse en lo formal, antes del pedimento del señor syndico, de su misma fecha.

Vistos: hase por apartado de su postura a Don Lorenso Porras y devuélvansele los recuados, tomándose las razones de su mérito. Pavón. Gómara. Obregón. Romá. Manrique. Gil. Oyarzával. Asturias.

Lo qual proveyeron y firmaron los señores del Cabildo, 22 Justicia / y Regimiento de esta ciudad. Nueva Guatemala y agosto diez y nuebe de mil setecientos ochenta y nucbe. Joseph Manuel de Laparte. 
En veinte del mismo, lo notifiqué al señor syndico Don Mariano de Náxera. Doy fe. Laparte.

En veinte y vno del mismo mes y año pasé vna esquela a Don Lorenso Porras en que se contiene lo determinado, para su inteligencia, por no haberle encontrado personalmente. / Se le devolvieron el [a]valúo de la casa, hecho por Nicolás Monzón, en quanto a carpintería, en que deduxo de valor seiscientos dos pesos tres reales, su fecha a los 19 de mayo del año de 788.

Se le devolvió el repectivo a albañilería que sube a tres mil seiscientos once pesos, hecho por Juan Ramires, en fecha de 22 de abril de 1789 . Vno y otro rubricado por mí.

Se le devolvió la cesión de Don Vicente Garzía de Salas, a favor de los propuestos de la deuda que a su favor tiene el dicho Porras, con fecha de 11 de agosto de 789, para resguardo de lo que reciva para esta función.

Igualmente se le devolvió el plán del teatro que presentó. Y para que conste lo firmó en 21 de agosto de 1789. Laparte. [A. G. G.-Fiestas (A. 1. 2-9), Legajo 2263, Expediente 16429].

1789

Sobre hacer comedias

Al señor syndico. Don Josef Guillermo Segura, en la mejor forma que haya lugar, parezco ante Vuestra Señoría en este mui Noble Ayuntamiento y digo: que hallándome con arvitrios para proporcionar una o tres comedias de los siguientes títulos: El desdén con el desdén; Primero es la bonra; $\mathrm{e}$ Yndustrias contra finezas, ${ }^{3}$ con que Vuestra Señoria Muy Ylustre puede celebrar la entrada del nuevo Muy Ylustre Señor Presidente; ${ }^{4}$ lo hago presente a su superior atención, ofreciéndole se representarán todas o la que sea de su maior agrado, sin ocasionar otro costo que el que tuviere la postura del teatro, la música y refrescos, con la calidad de que después se me conceda licenzia para que / representen en casas particulares, para sacar los costos que impendiere en pagar cómicos, vestuarios y músicos de ensayes (sic) sin mayor gravamen del público. $\mathrm{Y}$ en estos términos a Vuestra Señoría suplico se 
sirva providenciar lo que sea de su agrado. Joseph Guillermo Segura.

El decreto lo proveyeron y rubricaron los señores del Cabildo, Justicia y Regimiento Consejal. Nueva Guatemala y diziembre quatro de mil setecientos ochenta y nuebe años. Joseph Manuel de Laparte.

\section{$\mathrm{M} u y$ Ylustre Señor}

E1 síndico procurador general a esta vista dice: que la segunda parte de este pedimento de reprezentar esta laya de fiestas teatrales en casas particulares depende de la superioridad, pocición del govierno a quien podrá ocurrir, si pareciere conveniente. / Y en quanto a la primera, podrá Vuestra Señoría declarar ser inadmisible la propuesta de este suplicante, por deberse considerar que estos gastos los soportan los caudales de los particulares que sirven los oficios consejiles de este $\mathrm{Ca}$ bildo y su lasto no se eroga de el fondo y caxa de este-Noble Ayuntamiento y en esta superior no se admita en el particular más escrito, salbo lo que Vuestra Señoria determinare; que será como siempre lo mejor. Nueva Guathemala y diziembre 7 de 1789. Mariano Náxera.

Vistos: Hágase como dice en todo el señor syndico. Pavón. Gómara. Obregón, Ayzinena. Oyarzával. Asturias.

Lo qual proveyeron y firmaron los señores del Cabildo, Justicia y Regimiento de esta ciudad. En Nueva Guatemala y diziembre onze de ochenta y nuebe. Joseph Manuel de Laparte. /

En dicho día, mes y año, notifiqué el auto a Don Josef Guillermo Segura y quedó entendido. Doy fe. Segura. [A. G. G.-Diversiones (A. 1-16), Legajo 2312, Expediente 17145].

Juan José Núnes y Compañía de Bolatines sobre licencia para egerser sus avilidades. /

\section{Mzy Ylustre Señor}

Juan Joséh (sic) Núñez, de la compañía de bolatines que se halla en esta capital, ante Vuestra Señoría con el mayor respeto digo: que haviendo logrado el superior permiso de 
Vuestra Señoría para trabajar en todo género de habilidades, como son en maroma, saltos nunca vistos, alambre floxo, bayles, cuerda floxa, sombras chinescas, entremeses, sombras inpalpables, pantominas (sic) y comedias, he solicitalo del Muy Nable Ayuntamiento el patio de las casas de Cabildo y de la Hermandad de San Juan de Dios, el de Gallos y ninguno de los dos se me ha consedido. Después he agotado todos los recursos en busca de una casa particular con patio capaz de dar comodidad al becindario que concurra a las diberciones $y$ no la he allado absolutamente. En este estrecho, me beo presisado a molestar la atención de Vuestra Señoria, suplicándole se digne mandar se nos franque el patio del quartel de la plaza de Santa Rosa / que es de suficiente estención, protestando que no padecerá deterioro su fábrica y que qualquiera cosa que se descomponga en los enladrillados o empedrados, a nuestra costa se repondrá a toda satisfacción. En ello recibiremos bien y merced \&. Muy Ylustre Señor. Juan Joséh Núñez.

Real Palacio, dos de abril de 1803. Concédese el permiso que se pide para trabajar en las diversiones públicas que se expresan en el patio de la casa del quartel; con calidad de que, en cada uno de los días que se trabajen, hayan de darse por ahora seis pesos para el Hospital de San Juan de Dios, tomándose las providencias de policía acostumbradas en otras ocasiones semejantes y enterándose a los alcaldes ordinarios de primero y segundo voto, para que uno de ellos asista y esté al cuidado del buen orden de dichas diversiones. González. Ignacio Guerra.

(Derechos triplicados, con las certificaciones, once pesos.)

(Primera bara.) En sinco (sic) de abril de mil ochocientos tres, yo el escribano reseptor pasé a la casa de su mersed el alcalde ordinario de primer voto, Don Chriptóval Ortiz de Avilés, a quien inteligensié en lo prevenido en el auto que/ antesede y dijo que, para su cumplimiento en la parte que tocó a su ofisio, se le dé por la oficina de cámara certificasión relatiba de lo que contiene esta solicitud y su proveído. Esto dijo y lo firmó. De que doy fe. Avilés. Joseph Rodríguez Carballo, escribano reseptor.

(Segunda nominasión.) Ynmediatamente fuese en noticia este auto de su merced en el alcalde de segunda nominación y dixo que con que se le pase la misma certificación que pide su merced el alcalde de primer voto, para que no se multiple (sic) el trabajo de estender dos certificaciones, cumplirá con lo prevenido. Esto dijo y lo firmó. De que doy fee. Ayzinena. Joseph Rodríguez Carballo, escribano reseptor. 
(Hermano Mayor del Real Ospital (sic) de San Juan de Dios.) En la misma fecha yo el receptor pasé a notisia del Hermano Mayor de la Hermandad de Charidad Gratuyta, Don Pedro Ayzinena, el superior permiso que antesede, de que quedó enterado para la apersebsión de la limosna asignada a los pobres del mismo Real Ospital. $\mathrm{Y}$ para que conste, lo firmó y de ello hago / fe y pido certifico de la superior providencia. Quirós, secretario de la ermandad. Joseph Rodríguez Carballo.

En seis de abril, ochocientos tres, le hisiera ver el superior decreto a Don Joseph Núñez. Quedó enterado y firmó. De que hago fe. Joseph Rodríguez Carballo, escribano receptor. Juan Joseph Núñez.

$$
\begin{aligned}
& \text { pagos los } 11 \text { pesos de la oficina } \\
& \text { y más } 3 \text { pesos y en todo } \\
& \text { son } \quad 14 \text { pesos. }
\end{aligned}
$$

$Y$ puse en la oficina lo que le toca.

En trece del mismo se sacaron las correspondientes certificaciones de los alcaldes ordinarios y de la Hermandad de Caridad.

En la Nueva Guatemala, a diez y seis de abril de mil ochocientos tres. Don Juan Antonio Aqueche y Don Luiz Pedro de Aguirre, como diputado por / la Hermandad de Caridad del Real Hospital de San Juan de Dios, dieron cuenta al Muy Ylustre Señor Presidente de haberse combenido con una compañía de bolatines, en que hace cabeza Don Vicente Sánchez, sobre que, poniéndole un tablado, como de seis varas en quadro, en la cabezera del patio de Gallos de esta ciudad, dará dicha compañía al público todas sus havilidades de sombras chinescas, representación, bayles, pantominas y sombras impalpables y otras diversiones de noche, haciendo la compañía de su cuenta todos los gastos y diligencias necesarias para dichas diversiones, cobrando un real de entrada por cada persona; $y$ que por arrendamiento del patio de Gallos se cobrará por parte de la Hermandad para el hospital lo que su Señoría seña- / le por rasón de asciento, según las clasés da los que la misma Hermandad proporcionará al público, bajo la expresa condición de que las diverciones de la compañía no han de perjudicar la de Gallos, que hay en dicho patio los días permitidos, y que la compañía ha de dar allí presisamente sus diversiones, con exclusión sólo de lo que pertenece a maroma, columpio y saltos que por la estrechez del lugar no puede hacer allí y para lo qual se reserva impetrar licencia para hacerlo en algún patio por las tardes, siendo adbertencia que 
habrá diversión las noches de todos los dias de fiesta y las de los demás que permita el superior govierno. $\mathrm{Y}$ para que tenga cumplido efecto este combenio en todas sus partes, de orden del Muy Ylustre Señor Presidente / y por ante el presente escribano de Cámara Mayor de Govierno y Guerra, lo firmaron dichos diputados con el referido Don Vicente. De que certifico. Juan Antonio de Aqueche. Luis de Aguirre. Vicente Sánchez. Ignacio Guerra. [A. G. G.-Diversiones (A. 1-16), Legajo 150, Expediente 2923].

Govierno

Yndiferente

1813

Pío Castro sobre que se le conceda permiso para representar comedias en esta capital. Oficio mayor de govierno. /

Pío Castro de este vecindario ante Vuestra Excelencia en la mejor forma digo: que yo he estado en compañía de Don Miguel el mexicano, divirtiendo al público con algunas representaciones honestas de comedias escogidas en las noches de los dias festivos, por licencia que adquirió Don Miguel. Este trata de irse y el público está contento con mis representaciones, porque, teniendo en que divertirse el pueblo, se escusan las heridas y muertes que ocaciona la olgazanería (sic) y hebriedad. El juez, a cuio cuidado ha estado quel concurso, informará a Vuestra Excelencia, si es necesario, el arreglo que ha havido. Y, en esta virtud, a Vuestra Excelencia suplico se sirva concederme su superior permiso, para que pueda yo, siempre que cese Don Miguel, continuar la diverción de comedias escogidas, que al mismo tiempo que diviertan, instruyan $y$ excusen los delitos que trae la ociosidad; pues no pasaré de cobrar un real a los grandes y medio a los chicos, para facilitar su ingreso y el costo de los gastos que en la misma diverción tengo de inponder ( $\mathrm{sic}$ ), que, siendo merced, no es contraria a justicia. Pío Castro.

Real Palacio, enero doze de mil ochocientos trece. No ha lugar. Antonio Arroyave. En / trece del mismo lo hize saber al interesado. Quedó enterado. Doy fee. Pío Castro. Arroyave. [A. G. G.-Diversiones (A. 1-16), Legajo 150, Expediente 2935]. 
Mariano Arriaga solicita se le permita representar unas comedias. Oficio mayor de govierno. /

Don Mariano Arriaga, natural del Reyno de México y habecindado en la Antigua Guatemala ${ }^{5}$ hace ya seis años, como más lugar haya ante Vuestra Excelencia, paresco y digo con el respeto debido: que deceoso en dar una diversión honesta y deliciosa al vecindario de esta capital, me he propuesto verificarla con las piezas siguientes: Dragma (sic) cómico, El enemigo de las mugeres; El Marquez de Volipón y tonto Tirulito; La petrimeta (sic) corregida o señorita embustera; La fingida comedia y perdón de la enferma; Un loco bace ciento; El celoso Carranza; El minero y barras de plata; El muerto celoso; El chasco de los colegiales y el Crispin zapatero; El marido burlado; La bipocresía remedada y el sordo Tapia $^{6}{ }^{6}$ con otras muchas piezas curiosas, sus sainetes y cantos anegsos (sic), todo remedado en un treato (sic) pintoresco con un juego de estatuas de edad de siete años fingiendo las voses correspondientes, sin que intervengan mugeres en ello, ni contenga cosa alguna contra nuestra santa fe católica; guíenos contra lo político, antes bien moral instructivo, que inspira horror a los vicios; la mayor parte de lo representado es al estilo de México.

Si Vuestra Excelencia lo tiene ha bien dar esta diverción al público en las tres noches de la próxima Pascua, ofresco su desempeño y la puerta será con comodidad a medio real, comenzando y acabando a la hora acostumbrada de treato. En gracia que imploro \&. Mariano Arriaga.

Otrosí digo: que, para la execución dé la diverción, propongo a Vuestra Excelencia verificarla en la / casa misma en donde es el juego real del asiento de gallos de esta capital, lo que hago presente a Vuestra Excelencia para su superior resolución, manifestando si que la contribución de la entrada será la de un real por razón de la cuota o arrendamiento que se me exhije por cada noche por el dueño de la casa, que ofresco para más decoro y desaogo (sic) del público. Es merced que pido $v t$ supra. Mariano Arriaga.

Real Palacio, abril veinte y cinco de mil ochocientos diez y ocho. Pase al Excelentísimo Ayuntamiento y con lo que informe sobre cada vno de los particulares a que se contrae el escrito de Mariano Arriaga y acerca de su persona y calidades 
y con vista de las piezas que ofrece representar en el juego de gallos. Dése cuenta. Doctor Ybáñez. Felipe de Alvarado.

Cabildo / ordinario del viernes ocho de mayo de mil ochocientos dies y ocho. En atención a haber manifestado el señor síndico a quien se pasaron las piezas que se tratan de representar que no resulta de ellas ninguna cosa que pueda impedir su representación, evácuese el informe, manifestándolo así al Excelentisimo Señor Presidente. Asturias. Palomo. Yrigoyen. Zebadua. José Ynocente Calderón.

\section{Excelentísimo Señor}

En cumplimiento del decreto que presede y con vista de lo expuesto por el síndico de este Ayuntamiento aserca de la solicitud de Mariano Arriaga y de que las piezas que ofrese representar no contienen cosa por que se le deviese negar el permiso que solicita, ha parecido informar a Vuestra Excelencia que no hai incombeniente en que se le conceda para los tres días de la próxima Pascua. Sala Capitular de Guatemala y mayo ocho de mil ochocientos diez y ocho. Juan Asturias. Antonio Isidro Palomo. / Iñigo de Yrigoyen. Ysidoro de Valle y Camisiones. Marcial Zebadua.

Real Palacio. Mayo ocho de mil ochocientos diez y ocho. Al señor asesor general, agregando el interesado las piezas de que haze referencia. Felipe de Alvarado.

Por las muchas inquicisiones que he hecho para lograr noticia en donde exista Mariano Arriaga, se me informó por Don Tomás Nergara que se halla en la Antigua Guatemala, lo que hizo muchos días ha y para constancia pongo esta razón en seis de julio. Santiago Paniagua. /

\section{Excelentisimo Señor}

Don Mariano Arriaga, avecindado y casado en la Antigua Guatemala, como mejor lugar haya, ante Vuestra Excelencia paresco y digo: que en el presente año en los días de Pasqua de Pentecostés di con la licencia superior de Vuestra Excclencia diverción al público de esta capital, con unas dragmas cómicas representadas por estatuas y voces suplidas; $\mathrm{y}$ deseando continuar dando esta clase de divertimiento a este zuelo (sic), no puedo menos que ocurrrir a la autoridad y facultad superior de Vuestra Excelencia para que se digne concederme el permiso necesario, caso que lo tenga por com- 
beniente, empleándomelo hasta para el tiempo de Carnestolendas del año próximo entrante.

Pero, Señor Excelentísimo, mis deseos y particular súplica se contrae directamente a impetrar se me permita antes dar 0 hacer en este Real Palacio la diverción indicada en la noche del cumpleaños de Vuestra Excelencia o en la que guste dar este rato de entretenimiento a los niños, para que, en vista del contenido y método del acto de la diverción, examine si es anesca ( $\mathrm{sic}$ ) a esta capital la segunda parte de mi solicitud, que tengo impetrado en el principio, cuya gracia pido a Vuestro Excelencia con el más sumiso respeto; y juro no proceder de malicia \&. Mariano Arriaga.

Real / Palacio, octubre veinte y dos de mil ochocientos diez y ocho. Pase a informe del Excelentísimo Ayuntamiento. Cabildo ordinario del veinte y tres de octubre de ochocientos diez y ocho. Al señor síndico. José Ynocente Calderón. Conocimiento.

\section{Excelentisimo Señor}

El síndico dice que en esta fecha ha despachado otras dos solicitudes de igual naturaleza, vna de Francisco Martínez y otra de Don José María Alanís, y ha expuesto respectivamente su parecer. Consiguiente a éste, jusga que no es de concederse a Arriaga la licencia que pretende. Se embarazarían vnos a otros, si todos hubieran de dar sus diverciones a un mismo tiempo en un lugar en que basta un solo entretenimiento de esta naturaleza. Por lo que hace a Martínez, manifiesta el que subscribe en su respectivo expediente las razones en que / fun$\mathrm{d}_{\mathrm{a}}$ su dictamen $\mathrm{y}$, para que Alanís sea preferido a Arriaga, ha tenido en concideración que ofrece executar diversos entretenimientos y que la variedad tiene mucha parte en el placer que éstos puedan proporcionar. Además, es un profesor dedicado a este medio de vivir y acaso presentará una diverción más digna del público. Por todo lo qual se servirá Vuestra Excelencia informar que en caso de que se acceda a la solicitud de Alanís, se sirva el Excelentisimo Señor Presidente declarar sin lugar la del referido Arriaga. Guatemala, octubre 27 de 1818. Zebadua.

Cabildo ordinario del veinte y quatro de octubre de ochocientos diez y ocho. Como pide el señor síndico. José Ynocente Calderón. 


\section{Excelentisimo Señor}

Impuesto este Cabildo de la solicitud presente / y lo expuesto por $、$ el procurador síndico con respecto a ella y las otras que se han promovido de igual naturaleza, encuentra arreglado el pedimento anterior y lo reproduce en cumplimiento del superior auto de Vuestra Excelencia. Sala Capitular de Guatemala y octubre 27 de 1818. Juan Asturias. Juan José de Echeverrría. Vicente del Piélago. Gerónimo Malagani Vallarino. José María de Beltranena.

Real Palacio, octubre veinte y nueve de ochocientos diez y ocho. Al señor asesor general. Excelentisimo Señor. Felipe de Alvarado. /

El señor general dice: que las razones que tuvo el expediente por aconsejar se le negase a Francisco Martines la licencia que solicitó para representar comedias tiene aun mayor fuerza en la presente de Don Mariano Arriaga.

Por lo que estima el expediente se sirva Vuestra Excelencia declarar sin lugar esta solicitud. Guatemala, noviembre 7 de 1818. Doctor Ybáñez.

Real Palacio, noviembre nueve de mil ochocientos diez y ocho. Hágase como parese al señor asesor general. Vrrutia. Felipe de Alvarado. [A. G. G.-Diversiones (A. 1-16), Legajo 150, Expediente 2942].

Govierno

Yndiferente

1818

1

Francisco Martínez sobre que se le conceda licencia para representar unas comedias. Oficio mayor de govierno. /

\section{Excelentísimo Señor}

Francisco Martínez, ante Vuestra Excelencia en la mejor forma, paresco y digo: que, con el deseo de proporcionar al público un lugar decente y acomodado para el juego de gallos, fabriqué a mi costa el lugar en que ahora está. Su producto no me indemniza hasta el día de lo que he impendido en la fábrica y conservación de esta obra, saliendo perjudicado en lo que por cuenta del remate del asiento he satisfecho a la real hacienda. Va a fenecer el tiempo en que debe correr de 
mi cuenta y me es preciso con algún nuevo arbitrio buscar las utilidades que dejó de rendirme.

En los diversos tiempos en que se han representado en esta capital algunas comedias, se ha conocido el gusto del pueblo a este género de diversión. A pesar de la mala disposición de los teatros y las incomodidades de los sitios en que han estado, la concurrencia no faltó mientras subsistieron. Prueba nada equívoca de la inclinación del pueblo a las re- / presentaciones que sin duda no eran regulares por si debían acomodarse a las circunstancias, impericia de los actores y mala dirección de los ascentistas (sic). La utilidad de la representación de comedias en un pie regular es quizá mayor para el público que para el ascentista. La pleve inclinada a ellas se recoge por la noche en un lugar decente a la vista de un juez; se entretiene; y tal vez se logra enseñarla con algún fruto por este medio indirecto. Respecto de la otra parte del pueblo, es casi necesaria esta última ventaja.

En el día puedo hacer de la fábrica que tengo un teatro regular. Su forma ayuda mucho para el intento. $Y$ además de que está bien cubierto y es de suficiente capacidad, como se ha visto, proporciona otras comodidades del lugár, claridad y demás que penden de una buena disposición.

En lo que espero que Vuestra Excelencia tenga la bondad de prescribirme lo que deberé observar / y fuere de su superior agrado. De este modo puede darse una forma regular a esta diversión y producirme alguna utilidad al paso que se vaya adelantando.

Para todo esto es necesaria la protección de Vuestra Excelencia. El beneficio público, objeto de sus desvelos, lo inclinará desde luego a concedérmela y la utilidad, que espero sacar de este nuevo arbitrio que exige mi subsistencia y la de mi familia, me mueven a solicitar ahora la licencia necesaria. $\mathrm{Y}$ así, en consideración a todo lo expuesto, a Vuestra Excelencia suplico rendidamente se sirva concedérmela para que desde el $1^{\circ}$ de noviembre puedan ya comenzarse las representaciones desde las siete de la noche de los días festivos, en lo qual recibiré bien y merced, \&. Otrosí digo: que ofrezco dar a beneficio de la real hacienda cien pesos por la temporada en que corra de mi cuenta esta diversión. Francisco Martínez.

Real / Palacio, septiembre once de mil ochocientos diez y ocho. Pase a informe del Excelentisimo Ayuntamiento.

Cabildo ordinario del quince de septiembre de ochocientos diez y ocho. Al señor síndico. José Ynocente Calderón. En el mismo día se hizo saber al interesado. Calderón. 


\section{Excelentisimo Señor}

El síndico dice: que, aunque, Don José Oñate ha entablado con antisipación otra solicitud semejante, es distinta de la presente por contraherse (sic) a un coliceo per- / petuo $y$ ésta a una temporada de comedias $q u$ e se piensen representar en el patio de gallos. Anteriormente se puso allí una diverción de esta naturalesa y el exponente está informado de que no se guardó el orden debido acaso por las circunstancias del lugar. $\mathrm{Y}$, a efecto de inquirir si tiene las proporciones necesarias de firmeza, capacidad y demás que son de desearse para el buen arreglo de las concurrencias de esta clase, será conveniente que Vuestra Excelencia se sirva mandar una comición que con el exponente y un facultativo reconozca el lugar y su fábrica $y$, con vista de lo que resulte, se evacuará el informe que se prebiene. Guatemala, 17 de septiembre de 1818. Zebadua.

Cabildo ordinario del diez y ocho de septiembre de mil ochocientos diez y ocho. Como dice el señor síndico. Asturias. Echeverría. Palomo. José Ynocente Calderón.

\section{Excelentisimo Señor}

A efecto / de evacuar con algún fundamento el informe que Vuestra Excelencia se sirve pedir aserca (sic) de la presente solicitud, considera este Ayuntamiento, conducente las diligencias $q u$ e se expresan en pedimento anterior, $y$ al efecto se servirá Vuestra Excelencia mandarlas practicar si lo tubiere por combeniente. Sala Capitular de Guatemala y septiembre 18 de 1818. Juan Asturias. Juan José de Echeverría. Antonio Isidro Palomo.

Real Palacio, 19 de septiembre de 1818. De conformidad con el precedente informe del Excelentísimo Ayuntamiento de esta capital, se nombra al arquitecto Don Santiago Marqui, al alcalle $2^{\circ}$ Don Juan José Echeverría y al regidor Don Antonio Palomo para que en unión del síndico pasen a practicar el reconocimiento y diligencias que se expresan, dando cuenta.

\section{Excelentisimo Señor}

En cumplimiento de lo man- / dado por Vuestra Excelencia, el 19 del presente, en que se sirvió señalarme asociado con el señor alcalde segundo, el regidor Don Antonio Palomo y el síndico Don Marcial de Zevadua al reconocimiento del 
patio de gallos para resolver en la solicitud de Martínez, asentista del mismo, sobre querer formar coliseo en él, digo: que el techo que cubre el edificio estriva sobre débiles pilares de madera, los quales no tienen la devida consistencia, para sostener dicho peso y, siendo esta tierra muy propensa a temblores, es muy factible que al tiempo que el pueblo se haye (sic) congregado, para disfrutar del espectáculo, sobreviniera alguno, que haría sin duda lastimoso estrago en él; tanto más quanto carese de unas puertas amplias y prontas, que diesen lugar a la salida presipitosa que el pueblo haría en semejante situación. De suerte que, aun quando el temblor no fuera suficiente a derribar el edificio, pero serian inevitables las desgracias que habrian por la misma multitud que se atropellarían en las mismas puertas y escaleras tan angostas, que no darían lugar a una pronta salida.

Siendo así que no apruevo los fundamentos en que descansa esta obra, me parese inútil hablar sobre la figura rotunda que tiene, si es, o no, propia para coliseo. Esto es todo lo que devo decir en el particular, según los conocimientos que tengo en la materia. Nueva Guatemala y sepriembre 24 de 1818. Santiago Marqui.

\section{Excelentísimo Señor}

Hecha la calificación que se expresa en el infor- / me presedente sobre lo expuesto del edificio en que se pienzan tener las comedias que se solicitan, nada queda que agregar a los esponentes. Guatemala y octubre 2 de 1818. Excelentisimo Señor. Juan José de Echeverría. Antonio Isidro Palomo. Marcial Zebadua.

Real Palacio, dos de octubre de 1818. Al señor asesor. Felipe de Alvarado. /

\section{Excelentísimo Señor}

El maestro Francisco Martínez de este vecindario, con el más profundo respeto, ante Vuestra Excelencia digo: que, habiéndome presentado a Vuestra Excelencia, implorando su superior permiso para poner un teatro provisional o temporal de comedias, $y$, proponiendo executarlo en el edificio que sirve para la diversión de los gallos, se sirvió Vuestra Excelencia pedir informes al Excelentisimo Ayuntamiento y, de conformidad con el que dió, se mandó reconocer el edificio. 
Yo presencié el reconocimiento que hizo el arquitecto Don Santiago Marqui, por ante los señores capitulares comisionados, y vi al facultativo decir con repetición que el edificio estaba bastante bueno y seguro. Con esto manifesté mis disposiciones para acomodarlo a este nuevo destino y las obras que al efecto pensaba hacer; le propuse a Marqui que se encargase de dirijirme la obra del teatro, esto es el punto de la representación y demás necesario; aceptó y me ofreció tomarlo a su cargo; y así quedó concluido aquel acto. Estos hechos los presenciaron los referidos señores capitulares comisionados y yo pido a Vwastra Excelencia que sobre esto se sirva oír el informe de los mismos individuos, para que Vuestra Excelencia se persuada de mi veracidad y de la variación de ideas y juicio en que incurrió el facultativo.

En efecto, éste pidió el expediente para extender su informe y lo extendió con total contrariedad a lo que / anteriormente había manifestado. Lo sé, porque el mismo Marqui me lo mostró antes de que el expediente volviese a la oficina.

Dice que el techo del edificio no tiene consistencia, que decansa sobre débiles pilares, que está expuesto a caer con un temblor $y$ que, aun quando no cayere, siempre habría desgracia, porque no hay puertas amplias para que gente salga con prontitud en un lance semejante.

La solidez y seguridad de esta fábrica está provada $y$ experimentada. Antes de estrenarla para su primitivo destino, la reconoció el señor coronel Don Juan Bautista Jáuregui, por orden o encargo verbal del Excelentisimo Señor, antecesor de Vuestra Excelencia. ${ }^{7}$ La halló y calificó buena, formal y segura; lo informó así y entonces se me dió por escrito la licencia de que se usase y comenzase a servir.

Esto fué en el año le 815 . Después de aquella fecha ha padecido esta ciudad terremotos fuertísimos; los de los días 21 y 22 de julio de 816 y el que hubo a mediados de mayo de este año corriente han sido de los mayores que ha habido desde la ruina de la Antigua. Otros menos fuertes ha habido también y ni todos ellos ni los furiosos aguages de los dos años próximos anteriores han causado $1_{a}$ más leve lesión a la fábrica de que trato.

Por lo que hace a sus puertas, tiene tres, todas de muy regular amplitud. Las sombras o esqueletos de coliseos que ha habido aquí, después que se destruyó el único formal que se plantó más ha de veinte años; estos remedos de coliseo, digo, se han puesto siempre en sitios escasos, incómodos, descubiertos, desprovistos de todo, con una sola puerta, y esta puerta en dos de ellos, el que hubo en el antiguo patio / de gallos provisional y el del sitio que enfrenta con el patio actual, han 
sido mucho más estrechas que el del edificio de que voy hablando. Con todo, en estos lugares se han hecho las representaciones; ninguna desgracia ha sucedido y ahora viene Marqui, afectando un terror pánico contra mi patio que está a toda prueba y con bastantes proporciones, mayormente quando mi solicitud se ciñe a una sola temporada y no a un establecimiento perpetuo.

Por todo esto, Señor Excelentisimo, y porque (si he de hablar con verdad, sin faltar a la modestia debida) tengo fundamentos para rezelar que no ha sido imparcial el voto de Marqui y que se inclina a favorecer a Don José Oñate, que pretende (¡Ojalá lo logre!) poner formal coliseo $y$, creyendo que yo le estorvo, se interesa en que no ponga el mío temporal. Por esto, repito: no soy conforme con la opinión del citado profesor; le recuso, si es necesario, con el juramento debido, dejándolo en su buena opinión; y pido a Vuestra Excelencia se sirva nombrar al citado señor coronel Jáuregui, para $q u$, haciendo nuevo reconocimiento, informe a Vuestra $\mathrm{E} x$ celencia lo que le paresca, con vista del expediente, a cuyo efecto se le pase, recojiéndose o pidiéndose al Excelentísimo Ayuntamiento, que lo tiene para informar. También pido a Vuestra Excelencia se digne mandar enterar de esta mi gestión a aquel ilustre y noble cuerpo, para que suspenda su informe hasta las resultas del nuevo reconocimiento.

Por tanto, a Vuestra Excelencia suplico muy respetuosamente tenga la bondad de acceder a esta solicitud, proveyendo de conformidad en todos sus puntos, sirviéndose Vuestra Excelencia oír a los señores comisionados en orden a lo ocurrido con Don Santiago Marqui en el acto de su inspección; y, por último, reitero mi súplica de que Vuestra Excelencia me conceda su superior permiso, para el efecto / indicado, entendiéndose para toda la temporada del entrante verano, desde $1^{\circ}$ de noviembre hasta que regresen las llubias, vajo mi oferta de contribuir con la cantidad que dice mi primer escrito. En todo lo qual recibiré gracia, \&. Francisco Martíncz.

Real Palacio, septiembre treinta de mil ochocientos diez y ocho. Al señor asesor con el expediente del asunto, o sin él, si no huviere venido del Excelentisimo Ayuntamiento a donde pasó a informe.

\section{Excelentisimo Señor}

El asesor general dice: que Vuestra Excelencia puede servirse mandar se agregue el expediente a que se contrahe el escrito y superior auto de Vuestra Excelencia, luego que el Ex- 
celontísimo Ayuntamiento evacue su informe. Guatemala, octubre 6 de 1818. Doctor Ybáñez.

Real / Palacio, octubre seis de mil ochocientos diez y ocho. Hágase como parece al señor asesor general. Felipe de Alvarado.

En virtud de lo mandado, se agregan en quatro foxas los antecedentes a que se contrahe el este escrito, $v t$ supra. Alvarado.

\section{Excelentisimo Señor}

El / asesor general dice: que puede Vuestra Excelencia servirse mandar se pase este expediente al señor coronel de yngenieros Don Juan Bautista Jáurigi (sic) para que, haciendo previo reconocimiento del citio (sic) y fábrica que se designa, informe lo que hallare justo; que, evacuado este informe, vuelva al Excelentísimo Ayuntamiento porque, en vista de todo, determine Vuestra Excelencia lo conveniente. Guatemala, octubre 9 de 1818. Doctor Ybáñez.

Real Palacio, octubre nueve de mil ochocientos diez y ocho. Hágase como parece al señor asesor general. Felipe de Alvarado.

\section{Excelentísimo Señor}

En / cumplimiento del precedente decreto de Vuestra Excelencia, enterado del mérito de este expediente y hecho el reconocimiento de la pieza que sirve de patio de gallos, en los que pide permiso a Vuestra Excelencia Francisco Martínez para representar comedias, debo informar: que por lo que respeta a la firmeza del edificio de dicho patio no encuentro motivo de desconfiar de su seguridad; pues, aunque los pilares $\mathrm{q} u$ è sostienen su techo son delgados, pero de roble $\mathrm{y}$ de superior calidad, capaces de aguantar muchísimo peso, como lo han acreditado con la experiencia de tres años que hace que están sirviendo y particularmente en los primeros meses de su estreno con una concurrencia tan grande de gente que con dificultad asistirá tanta a las comedias. Además, está de llano en aumentar otro pilar en medio de cada vano de los que sostienen el piso superior, con lo que quita hasta el menor recelo que pueda haber. La puerta de la entrada es reducida, pero está con intención de ensanchar hasta dos varas y quedaría bastante capaz. Las dos escaleras para el piso superior son angostas, pero, como en él es poca la gente que cave, no 
hay motivo para que haya atropellamiento. Además, está resuelto en hacer otra más capaz en uno de los costados.

Con estas obras y las demás / que tiene proyectadas para el tablado en que se han de representar y los palcos que han de servir para Vuestra Excelencia y el juez que ha de precidir, me parece que ha de quedar un coliseo seguro $y$ bastante acomodado y únicamente podrá tener el defecto de ser algo reducido y esto solamente perjudica al asentista que tendrá menos utilidad; pero será mucho más cómodo para los espectadores que quantos provisionales ha habido aquí, que, generalmente han sido en los patios al raso y en éste estarán debaxo de cubierta libres del sereno.

En esta atención, soy de parecer que Vuestra Excelencia, si lo tiene a bien, se sirva dar al suplicante el permiso que solicita, con la condición de que, antes de principiar las comedias, se vuelva a reconocer por un inteligente que Vuestra Excelencia nombre, para ver si están bien executadas las mencionadas obras. Guatemala, 20 de octubre de 1818. Excelentísimo Señor. Juan Bautista de Jáuregui.

Cabildo / ordinario del veinte y tres de octubre de ochocientos diez y ocho. Al señor síndico. José Ynocente Calderón. Conocimiento.

\section{Excelentisimo Señor}

El síndico dice: que, a efecto de poder hablar con conocimiento sobre la presente solicitud, pidió anteriormente que una condición asociada del que habla y un facultativo reconociese el patio de gallos donde el suplicante piensa hacer las comedias que se ha propuesto. Se hizo el reconocimiento y, aunque el arquitecto Don Santiago Marqui manifestó en el' acto una opinión favorable, refleccionando con mayor detención, extendió su informe, expresando un juicio contrario en fuerza de las razones que indica.

La que mira a la poca solidés del edificio acaso será la de menor importancia por ser fácil de remediar este inconveniente con las precauciones que expresa en su informe el señor coronel Don Juan Bautista Jáurigi (sic). Pero, vencido este obstáculo, aun quedan otros que parecen insuperables. Uno de ellos es la extrechura de las escaleras y puertas, que no pu19 dién- / dose trancitar (sic) sino de uno en uno, no ofrecen al público una fácil y pronta salida en caso de necesidad. Un temblor, el miedo sólo ocacionado por la voz de un mal intencionado, puede en semejante lugar poner los ánimos en movimiento y causar muchas desgracias. Muchos exemplos de 
esta clase ha mostrado la experiencia: los efectos de un vano temor movido de la voz ligera de que peligraba la plaza en una fiesta de toros en Madrid, causaron la muerte de muchos que encontraron el riezgo en los medios con que creían salvar la vida; y apenas bastó la presencia de Felipe IV para asegurar los ánimos. Otras desgracias iguales han ocurrido en diversos lugares de España y, si la experiencia debe ser la guía que nos govierne, menester es que concluyamos que no se debe exponer la seguridad pública al ligero placer de una diverción, mucho más, quando en la actualidad pueden substituirse otras. Tales son las corridas de toros de que se halla tratando la Hermandad de Caridad y las que por la noche se propone dar Don José María Alanís de pantominas (sic), representaciones drammáticas y otras varias. Exe- / cutándose éstas en una casa cómoda, el público se entretendrá con seguridad y el comicionado que presida podrá zelar (sic) con facilidad, cosa que es impracticable en el patio de gallos donde por su forma no hay un punto que domine, siendo éste otro de los inconvenientes que presenta.

En esta atención, y, no pudiendo esta ciudad soportar por otra parte tantas diverciones a un ticmpo, el síndico es de parecer que se evaqüe el informe pedido, haciendo estas reflecciones, y que, en consecuencia de ellas, se sirva el Excelentísimo Señor Presidente negar su superior permiso. Guatemala, octubre 27 de 1818 . Zebadua.

Cabildo ordinario, del veinte y quatro de octubre de ochocientos diez y ocho. Como dice el señor síndico. Asturias. Echeverría. Piélago. José Ynocente Calderón.

\section{Excelentísimo Señor}

Este Ayuntamiento, encontrando conforme / el pedimento de su síndico, lo reproduce en todas sus partes y Vuestra Excelencia se servirá resolver como en él se expresa. Sala Capitular de Guatemala y octubre 27 de 1818. Juan Asturias. Juan José de Echeverría. Vicente del Piélago. Gerónimo Machagani Vallarino. José Maria de Beltranena.

Real Palacio, octubre veinte y nueve de ochocientos diez y ocho. Al señor asesor general. Felipe de Alvarado. /

\section{Excelentisimo Señor}

El maestro Francisco Martínez, con el mayor respeto, ante Vuestra Excelencia digo: que a mi instancia y por la recusación que puse al arquitecto Don-Santiago Marqui, se sirvió 
Vuestra Exclencia mandar pasar a informe del señor coronel de ingenieros Don Juan Bautista Jáuregui, el expediente de mi solicitud, sobre que se me conceda licencia para un coliseo provisional y entiendo que dicho señor evacuó el informe a favor de mi intención.

En este concepto, me parece que ya no habrá obstáculo, pero para el evento de que aun se pulze (sic) alguna dificultad por la qual Vuestra Excalencia no tenga a bien dar su superior permiso para que el coliseo se sitúe en el patio de gallos; desde luego, me allano a que sea en otro sitio y propongo para tal caso el que enfrenta con el mismo patio u otro de dos que hay allí inmediatos, $y$ son todos muy amplios y aparentes. Es verdad que ninguno reune las ventajas del patio, que está cubierto, con asientos firmes y otras comodidades, pero, en el que se elija por esta superioridad, procuraré proporcionar, quanto me sea posible, para la mayor decencia y comodidad del público.

Ya sea en uno de estos sitios, ya en el indicado del patio, yo repito a Vuestra Excelencia mis humildes súplicas de que se digne otorgarme su superior permiso para el teatro provisional, por sola la temporada de este verano. $Y$, con el fin de que Vuestra Excelencia se persuada de mis motivos para instar por esta gracia, no puedo dejar de representarle sumisamente $\mathrm{q} u e$, en atención a $\mathrm{q} u \mathrm{e}$ los señores comisionados que practicaron el primer reconocimiento del patio, me digeron q $u$ e podía ir tomando mis disposiciones $\mathrm{y}$ haciendo mis preparativos y el arquitecto también aprovó el sitio, segín ya manifesté en otro escrito. Confiado yo en estas circunstancias $\mathrm{y}$ en la insinuación del señor alcalde segundo y del síndico procurador general, ya / no tube dificultad en irme apercibiendo para que se realizase la representación. Tengo ya ensayadas algunas comedias, pagados los cómicos y hechos otros muchos gastos que pudiera yo acreditar, sin contar con las costas de este expediente; de modo que, si no se me concediera la licencia, sufriria yo un gran quebranto.

Además, Señor Excelentísimo, los que he sufrido y estoy sufriendo en el asiento de gallos, que no me da ni lo preciso para pagar los arrendamientos a la real hacienda $y$ en que lejos de percibir la menor utilidad, he tenido que sacrificarme $y$ poner mucho de mi peculio. Es otra de las razones que me obligan a buscar en el coliseo alguna indennización (sic) que compenze (sic) mis pérdidas en el remate de gallos. Y yo no dudo que todo esto inclinará el ánimo piadoso y benigno de Vuestra Excelencia en favor de mi solicitud. Por tanto, pues, a Vuestra Excelencia encarecidamente suplico sea muy servido de otorgarme su superior permiso en los términos que lo 
tengo implorado $y$, quando no tenga a bien concederlo para el patio, que se digne Vuestra Excelencia darlo para el sitio que fuese de su superior agrado, en qualquiera de los propuestos; que en ella recibiré gracia y merced, \&. Francisco Martínez.

Real Palacio, octubre veinte y nueve de ochocientos diez y ocho. Agréguese a sus antecedentes que se han mandado pasar al señor asesor general. Excelentisimo Señor. Felipe de Alvarado.

El / asesor general dice: que, aunque el señor coronel de yngenieros informa que se puede acceder a la solicitud de Francisco Martines, es con varios requisitos que exige. El Excelentisimo Ayuntamiento se opone por las razones que individualisa su síndico procurador. Las que Martines ha alegado posteriormente no enervan la fuerza de aquéllas.

Al expediente le parece que aun prescindiendo de las dificultades que se palpan en lugar y edificio de la scena (sic), el interés público demanda que no se acceda a la presente licencia, pues que, así como le es útil una moderada diverción, le es perjudicial la abundancia.

Por lo que se servirá Vuestra Excelencia declarar no haver lugar a la licencia que inpetra Francisco Martines. Guatemala, noviembre 2 de 1818 . Doctor Ybáñez.

Real / Palacio, noviembre tres de mil ochocientos diez y ocho. Hágase como parece al señor asesor general. Urrutia. Felipe de Alvarado.

En veinte del mismo lo hize saber en su persona a Francisco Martínez, quien no firmó, porque fué en la plaza de toros en donde se halló apreciando a la construcción. Doy fe. Santiago Paniagua. [A. G. G.-Diversiones (A. 1-16), Legajo 150, Expediente 2943].

Gobierno

El Excelentisimo Ayuntamiento sobre que a él corresponde dar la licencia que Don Cayetano Bedoya solicita para representar comedias. Oficio de guerra. /

Palacio de Guatemala, 25 de octubre de 1820 . Pase en consulta con los antecedentes de la materia que se hallan en la escribania de cámara, con la real orden de la regencia de 13 de julio de 1813, y carta acordada del superior Consejo de Yndias de 18 de agosto de 1819 a la Excelentisima Diputación Provincial. Urrutia. 


\section{Excelentisimo Señor}

Don Cayetano Bedoya, acaso sin conocimiento del soberano decreto de 11 de diciembre de 812 , se dirijió a Vuestra Excelencia en solicitud de que se le diese permiso para abrir un coliseo provicional en esta ciudad, cuyo expediente se pasó a informe de este Ayuntamiento.

Para evaquarlo quiso oír la opinión de sus síndicos, los quales, con fecha de 11 del corriente y fundados en el citado decreto, sostienen ser exclusivo de los Ayuntamientos todo lo relativo a diverciones públicas y arreglo de teatro y concluye con que se oficie a Vuestra Excelencia, manifestándole lo decisivo de la citada soberana disposición, para que se sirva sobreseer en el conocimiento de dicha solicitud, ínterin evaqúan su pedimento sobre lo principal.

En seción (sic) ordinaria de hoi se ha conformado este cuerpo con la moción de sus síndicos, apoyado en las prevenciones del citado decreto que dice: $1^{\text {* }}$ Los Ayuntamientos harán por sí con los empresarios de las compañías cómicas los convenios que concideren / oportunos, conciliando el interez (sic) de la empresa con el de los pueblos. $2^{a}$ Deverá presentarse lista de las piezas dramáticas que compongan el caudal de la compañía al xefe (sic) político de la provincia, quien excluirá las que en su concepto se opongan a las buenas costumbres, reduciéndose a esto todas las atribuciones sobre la materia.

En su consequencia, espera el Cabildo que Vuestra Excelencia se sirva sobreseer en el particular, dejándole en la libertad que le da aquella soberana disposición.

Dios guarde a Vuestra Excelancia muchos años. Sala Capitular de Guatemala, octubre 16 de 1820. Excelentisimo Señor. Ramón Ramírez. Miguel José Manrique. José Antonio de Larrave. Manuel Ramírez. José Venancio López. Excelentísimo Señor Don Carlos de Urrutia, xefe político superior de la provincia. / Gobernación de ultramar. Contada, 3 diziembre, 813. Nímero.

El Señor Secretario de Estado y del Despacho de la Gobernación de la Península me ha participado con fecha 6 de este mes, lo que con la de 11 de diciembre de 1812 circuló a los gefes políticos superiores de la misma península e yslas adyacentes y es lo que sigue:

"Deseando la regencia del reyno arreglar el ramo de teatros de un modo que sin perjuicio del honesto recreo de los pueblos ni del interés de los cómicos, asegure el respeto devido 
a la moral y a la conservación del orden público, se ha servido resolver lo que sigue:

$1^{\circ}$ Los Ayuntamientos harán por sí con los empresarios de las compañías cómicas los convenios que consideren oportunos, conciliando el interés de la empresa con el de los pueblos.

$2^{\circ}$ Deverá presentarse lista de las piezas dramáticas que compongan el caudal de la compañía al gefe político de la provincia, quien excluirá las que en su concepto se opongan a las buenas costumbres, reduciéndose a esto todas sus atribuciones en la materia.

$3^{\circ}$ Los Ayuntamientos de los pueblos cuidarán inmediatamente por sí de los pormenores relativos a la policía de los teatros, haciendo cumplir los reglamentos dirigidos a conservar el orden, la tranquilidad y la decencia, tanto por parte de los actores como de los expectadores.

$4^{\circ}$ La administración del fondo y ganancias de la compañía correrá de cuenta del empresario, ciñendo los Ayuntamientos sus funciones en esta parte a la intervención indispensable para que se cumplan fiel y legalmente las cargas que puedan imponerse, con arreglo al ajuste, sobre el producto de los teatros para objetos de beneficio común.

$5^{\circ}$ En cuanto al gobierno y dirección interior de las compañías / los cómicos se entenderán con el autor o el empresario, según sus pactos particulares. Si con motivo de éstos se suscitasen desabenencias entre unos y otros, los Ayuntamientos procurarán terminarlas gubernativa y prudencialmente $y$, en el caso de no conformarse los interesados con la decisión del Ayuntamiento, acudirán al tribunal correspondiente como en qualquiera otro contrato."

De orden de Su Alteza lo comunico a Vuestra Excelencia para su inteligencia y cumplimiento y que para iguales fines Io translade a los Ayuntamientos del distrito de su mando superior, dando cuenta de su recivo y de haberlo circulado.

Dios guarde a Vuestra Excelencia muchos años. Cádiz, 13 de julio de 1813. José de Pimentel.

Señor Capitán General, gefe político de Guatemala: Real / Palacio, $1^{\circ}$ de noviembre de 1813. Cúmplase lo mandado por $\mathrm{S} u$ Alteza en esta orden y para ello comuníquese al Ayuntamiento de esta capital y a las intendencias y alcaldías mayores para que la circulen a los del distrito de su mando. Bustamente. / 
Al Rey Nuestro Señor y el Consejo Supremo de Yndias se le ha dado noticia de estarse construyendo en esa ciudad un coliseo para la representación de comedias, contra lo espresamente dispuesto en la real cédula de 9 de octubre de 1794, y para costar los daños que de ello pueden seguirse y que se proceda en el asunto con todo conocimiento ha resuelto disponga Vuestra Excelencia se formalice el espediente instructivo en la forma que se previno en dicha real cédula y lo remita para la resolución con su informe acerca de la conveniencia o perjuicios que en el estado presente de las cosas pueda tener dicho establecimiento, sin permitir que entretanto se hagan tales funciones públicas. $Y$ de acuerdo de dicho supremo tribunal lo participo a Vuestra Excelencia para su inteligencia y cumplimiento.

Dios guarde a Vuestra Excelencia muchos años. Madrid, 18 de agosto de 1819. Esteban Varea.

Señor Capitán General y Presidente del Reyno de Guatemala: / [Los] antecedentes, que se mandan agregar, no existen en esta escribanía de mi cargo sino en el Excelentísimo Ayuntamiento a donde se pasaron a informe; y para constancia siento esta razón. Guatemala, 27 de octubre de 820 . Zelaya.

\section{Excelentísimo Señor}

Con vista de la real orden de la regencia de 13 de julio de 813, opina la diputación: que Vuestra Excelencia puede sobreseer en este negocio y mandar se pase al Excelentísimo Ayuntamiento, a quien corresponde toda la política de los teatros, puesto que por la citada orden sólo toca a los gefes políticos el conocimiento de las piezas dragmáticas (sic) que hayan de representarse, para escluir las que se opongan a las buenas costumbres. Diputación Provincial de Guatemala. Enero 29 de 821. Excelentisimo Señor. Beltranena. Calderón. Morena. Vaca.

Pala- / cio de Guatemala, $1^{\circ}$ de febrero de 1821. Hágase como parece a la Excelentísima Diputación Provincial, sacándose testimonio y dándose cuenta a $S u$ Majestad con la consulta correspondiente. Urrutia. José Ramón Zelaya.

(Son 7 foxas escritas, cada una reverso blanco.) 
En nueve de dicho se sacó testimonio por principal de este expediente para dar cuenta a $\mathrm{S} u$ Majestad, en virtud de lo mandado y en la misma fecha por duplicado. Zelaya. Govierno mayor. [A. G. G.-Diversiones (A. 1-16), Legajo 150, Expediente 2950 ].

\section{NOTAS A LOS DOCUMENTOS}

1 Los curatos de Sanzaria y Tocoy fueron creados en el siglo xvmi y pertenecieron a la vicaría de San Agustín de la Real Corona. El nombre de valle se daba a aquellas poblaciones que no tenían "iglesia ni otras formalidades de pueblo." Véase Domingo Juarros, Compendio de la historia de la cindad de Guatemala, $3^{3}$ edición, Guatemala, 1937, I, 68-71.

2 El mayor monstruo, los celos es de Calderón de la Barca. Antioco y Seleuco es probablemente el drama de Moreto, pero hay también una obra burlesca del mismo título, escrita por tres ingenios. La confusion de un jardin también es de Moreto. Véase Francisco Medel del Castillo, Indice general alfabético de todos los títulos de comedias, reimprímelo John $\mathrm{M}$. Hill, extrait de la Revue Hispanique, 1929, Lxxv, 16, 29, 70.

3 El desdén con el desdén, Primero es la honra e Industrias contra finezas son de Moreto.

4 El Excelentísimo Señor Don Bernardo Troncoso Martínez del Rincón, Teniente General de los Reales Ejércitos obtuvo sucesivamente los empleos de Teniente de Rey de la Plaza de La Habana, Gobernador de Veracruz y Presidente, Gobernador y Capitán General de Guatemala. Entró en Guatemala el 31 de diciembre de 1789 y gobernó hasta el 25 de mayo de 1794 . Véase Juarros, op. cit., I, 194. El presidente Troncoso, afecto al teatro, avisó al rey con fecha 20 de febrero, de 1794: "Entre las diferentes medidas que he adoptado a fin de suavizar las feroces costumbres de la plebe de esta capital sanguinaria hasta no más y propensa a la embriaguez, ha sido proporcionarle un coliseo de dos o tres comedias cada semana." Reproducida por Antonio Batres Jáuregui, Memorias de antaño, Oakland, Cal., 1896, p. 208.

5 No todos los habitantes abandonaron a la Antigua Guatemala después tel terrible terremoto del 29 de julio, de 1773, que demolió tantos edificios magníficos. Su destrucción indujo a las autoridades civiles a establecer otra capital, a la cual se la nombró Nueva Guatemala de la Asunción. Véase Pedro Pérez Valenzuela, La Nueva Guatemala de la Asumción, Guatemala, 1934; Ramón A. Salazar, Historia del desenvolvimiento intclectual de Guatemala: La colonia, Guatemala, 1897, I, 12-15. 
6 El enenigo de las mijeres, de Ramón de la Cruz, es desconocido. La obra en cuestiótn será probablemente la traducción de La locandiera, de Goldoni, hecha por José López de Sedano, hacia 1779, e impresa en Madrid, en 1799. Véase Emilio Cotarelo y Mori, Don Ramón de la Cruz y sus obras, Madrid, 1899, p. 329; Paul Patrick Rogers, Goldoni in Spain, Oberlin, Ohio, 1941, pp. 83-85. María Rosa de Gálvez de Cabrera escribió Un loco hace ciento, comedia en un acto, en prosa, Madrid, 1801. Véase Ada M. Coe, Catálogo bibliográfico $y$ crítico de las comedias amunciadas en los periódicos de Madrid desde 1661 hasta 1891; The Johns Hopkins Studies in Romance Literatures and Languages, 1935, extra vol. Ix, 84-85. Hay un entremés que se titula La preñada de deseo y marido burlado. Véase Julián Paz, Catálogo de las piezas de teatro, etc., $2^{\mathrm{i}}$ edición, Madrid, 1934, vol. I, núm. 2955.

7 El antecesor a quien se refiere fué el general don José de Bustamante y Guerra. El 14 de marzo de 1811 éste tomó posesión del gobierno en Guatemala y el 28 de marzo de 1818 entregó el mando al general don Carlos de Urrutia y Montoya, quien fué el último de los gobernantes nombrados directamente por el Rey de España. Véase J'. Antonio Villacorta C., Historia de la Capitanía General de Guatemala, Guatemala, 1942, p. 80.

\author{
Harvey L. Johnson, \\ Indiana University, \\ Bloomington, Indiana.
}

